\title{
Effect of Wheat Residue Management and Fertilizer Levels on Growth and Yield of Fodder Maize (Zea mays L.)
}

\author{
A.S. Patil ${ }^{1 *}$, B.M. Dabhi ${ }^{1}$ and M.S. Shitap ${ }^{2}$ \\ ${ }^{1}$ Department of Agronomy, ${ }^{2}$ Department of Agricultural Statistics, College of Agriculture, \\ Junagadh Agricultural University, Junagadh-362001, Gujarat, India \\ *Corresponding author
}

\section{A B S T R A C T}

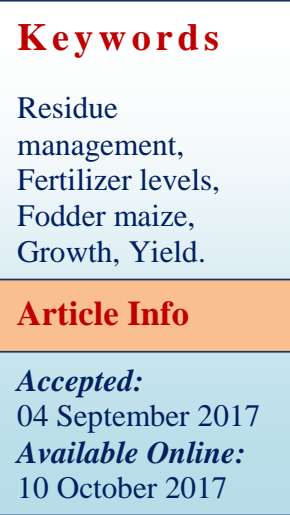

Keywords

Residue

Growth, Yield.

Article Info

Accepted:

Available Online:

10 October 2017
Field experiment was conducted at Farming System Research Centre, AICRP-IFS, Department of Agronomy, College of Agriculture, Junagadh Agricultural University, Junagadh, Gujarat on medium black soil during summer season of 2015 and 2016 to study the effect of wheat residue management and fertilizer levels on growth and yield of fodder maize (Zea mays L.). Data revealed that among different residue management treatments, harvesting through combine harvester and straw incorporation in soil $+5 \mathrm{~kg}$ madhyam + $25 \mathrm{~kg} \mathrm{~N} \mathrm{ha}^{-1}$ recorded higher plant height, no. of leaves plant ${ }^{-1}$, leaf area index, leaf chlorophyll content, stem diameter, no. of internodes plant ${ }^{-1}$, dry matter plant ${ }^{-1}$ and fodder yield followed by harvesting through combine harvester and straw incorporation in soil +5 $\mathrm{kg}$ Trichoderma $+25 \mathrm{~kg} \mathrm{~N} \mathrm{ha}^{-1}$. Among different fertilizer levels application of $100 \% \mathrm{RDF}$ recorded significantly highest plant height, no. of leaves plant ${ }^{-1}$, leaf area index, leaf chlorophyll content, stem diameter, no. of internodes plant ${ }^{-1}$, dry matter plant ${ }^{-1}$ and fodder yield over rest of the levels.

\section{Introduction}

Maize (Zea mays L.) is one of the most important fodder crop all over the world. It is also fondly called as a "king of fodder" due to its great importance in animal diet, as it can be grown throughout the year mainly due to its photo-thermo-insensitive character. Among the cultivated non-legume fodder as well as grain crops, maize is the most important cereal crop in India, which can be grown in all the three seasons- kharif, rabi and summer. Maize is cultivated in diverse production environments ranging from temperate hill zone to the semi-arid region (Singhal, 2003). Sustainable food and nutrition security involves meeting current need in agriculture production without sacrificing the prospects for meeting the need of future generation.

We have to produce more and more from less and less land. This would necessitate optimization of our efforts in land utilization, soil and moisture conservation with greater emphasis on residue management with adequate nutrition through fertilizers. In the light of these observations an experiment was laid out to know the effect of residue management and fertilizer levels in fodder maize on growth and yield. 


\section{Materials and Methods}

A field experiment was conducted at Farming System Research Centre, AICRP-IFS, Department of Agronomy, College of Agriculture, Junagadh Agricultural University, Junagadh, on medium black soil during summer season of 2015 and 2016 to study the effect of wheat residue management and fertilizer levels on fodder maize (Zea mays L.) in medium black soils of Saurashtra.

There were total fifteen treatment combinations comprising of five residue management practices $\left(\mathrm{R}_{1}\right)$ no residue incorporation (Manual harvesting), $\left(\mathrm{R}_{2}\right)$ harvesting through combine harvester and burning the straw, $\left(\mathrm{R}_{3}\right)$ harvesting through combine harvester and straw incorporation in soil, $\left(\mathbf{R}_{4}\right)$ harvesting through combine harvester and straw incorporation in soil +5 $\mathrm{kg} T$. viride $+25 \mathrm{~kg} \mathrm{~N} \mathrm{ha}{ }^{-1}$ and $\left(\mathrm{R}_{5}\right)$ harvesting through combine harvester and straw incorporation in soil $+5 \mathrm{~kg}$ madhyam + $25 \mathrm{~kg} \mathrm{~N} \mathrm{ha}^{-1}$ assigned to main plot and three fertilizer levels as a sub plot treatments viz., $\left(F_{1}\right)$ control, $\left(\mathrm{F}_{2}\right) 50 \% \mathrm{RDF}$ and $\left(\mathrm{F}_{3}\right) 100 \%$ RDF were tried out in Split Plot Design (SPD) with three replications.

All agronomical practices were followed during investigation period and meteorological week wise weather parameters also observed. The net plot wise yield was recorded and subjected to statistical analysis Cochran and Cox (1957).

\section{Results and Discussion}

\section{Effect of wheat residue management}

The growth parameters (Table 1) were markedly influenced by residue management. Significantly higher plant height $(219.1 \mathrm{~cm})$, number of leaves plant ${ }^{-1}$ (18.6), leaf area index (15.70), leaf chlorophyll content
(53.71), stem diameter $(1.92 \mathrm{~cm})$, number of internodes plant $^{-1}$ (15.13) and dry matter plant $^{-1}(99.61 \mathrm{~g})$ was recorded in $\mathrm{R}_{5}$ (harvesting through combine harvester and straw incorporation in soil $+5 \mathrm{~kg}$ madhyam + $25 \mathrm{~kg} \mathrm{~N} \mathrm{ha}{ }^{-1}$ ) as compared to rest of the treatments except $\mathrm{R}_{4}$ (harvesting through combine harvester and straw incorporation in soil $+5 \mathrm{~kg}$ T. viride $\left.+25 \mathrm{~kg} \mathrm{~N} \mathrm{ha}^{-1}\right)$.

It is the fact that microbial culture along with $\mathrm{N}$ might have increased decomposition of residue during that they releases growth factors which plays role in cell division, cell elongation and progressive initiation of tissues and organ differentiation and expansion of component cell thereby enhanced growth parameters (Meena and Singh, 2013 and Soleymani et al., 2016).

The data depicted in table 1 showed that harvesting through combine harvester and straw incorporation in soil $+5 \mathrm{~kg}$ madhyam + $25 \mathrm{~kg} \mathrm{~N} \mathrm{ha}{ }^{-1}\left(\mathrm{R}_{5}\right)$ recorded significantly higher fodder yield $\left(54057 \mathrm{~kg} \mathrm{ha}^{-1}\right)$ but it was on same bar with $\mathrm{R}_{4}$ (harvesting through combine harvester and straw incorporation in soil $+5 \mathrm{~kg} \mathrm{~T}$. viride $+25 \mathrm{~kg} \mathrm{~N} \mathrm{ha}^{-1}$ ). This might be due to, yield of crop is a function of several yield components which are dependent on complimentary interaction between vegetative and reproductive growth of crop.

A significant increase in green fodder yield under these treatments because, straw incorporation with microbial inoculants leads to faster decomposition of straw, improved the status of soil organic matter, leading to higher uptake of available nutrients from soil and ultimately increased the growth and yield components.

The results are in accordance with the results obtained by Singh and Yadav (2006) and Rajkhowa and Borah (2008). 
Table.1 Effect of wheat residue management and fertilizer levels of growth and yield of fodder maize

\begin{tabular}{|c|c|c|c|c|c|c|c|c|}
\hline Treatments & $\begin{array}{l}\text { Plant height } \\
(\mathrm{cm})\end{array}$ & $\begin{array}{c}\text { No. of } \\
\text { leaves plant }_{1}^{-}\end{array}$ & $\begin{array}{l}\text { Leaf area } \\
\text { index }\end{array}$ & $\begin{array}{c}\text { Leaf } \\
\text { chlorophyll } \\
\text { content }\end{array}$ & $\begin{array}{c}\text { Stem } \\
\text { diameter } \\
(\mathrm{cm})\end{array}$ & $\begin{array}{c}\text { No. of } \\
\text { internodes } \\
\text { plant }^{-1}\end{array}$ & $\begin{array}{l}\text { Dry matter } \\
\text { plant }^{-1} \\
(\mathrm{~g})\end{array}$ & $\begin{array}{l}\text { Fodder yield } \\
\qquad\left(\mathrm{kg} \mathrm{ha}^{-1}\right)\end{array}$ \\
\hline \multicolumn{9}{|c|}{ Main plot (Crop residue management: $R$ ) } \\
\hline $\mathrm{R}_{1}$ & 189.7 & 15.5 & 14.62 & 48.70 & 1.62 & 11.85 & 86.16 & 39936 \\
\hline $\mathrm{R}_{2}$ & 185.8 & 15.1 & 14.24 & 47.48 & 1.59 & 11.45 & 82.92 & 37620 \\
\hline $\mathrm{R}_{3}$ & 197.3 & 16.7 & 15.13 & 49.89 & 1.75 & 13.87 & 91.82 & 45625 \\
\hline $\mathrm{R}_{4}$ & 215.7 & 18.1 & 15.33 & 52.17 & 1.88 & 14.85 & 98.02 & 51366 \\
\hline $\mathrm{R}_{5}$ & 219.1 & 18.6 & 15.70 & 53.71 & 1.92 & 15.13 & 99.61 & 54057 \\
\hline S.Em \pm & 4.8 & 0.4 & 0.21 & 0.79 & 0.05 & 0.42 & 1.28 & 1288 \\
\hline C. D. at $5 \%$ & 14.3 & 1.2 & 0.64 & 2.37 & 0.15 & 1.27 & 3.84 & 3860 \\
\hline C.V. $(\%)$ & 10.1 & 10.6 & 10.86 & 6.66 & 12.48 & 13.40 & 5.88 & 12 \\
\hline \multicolumn{9}{|c|}{ Sub plot (Fertilizer levels: F) } \\
\hline $\mathrm{F}_{1}$ & 181.1 & 15.2 & 14.12 & 47.49 & 1.58 & 11.88 & 86.71 & 39668 \\
\hline $\mathrm{F}_{2}$ & 203.2 & 16.5 & 15.05 & 50.15 & 1.74 & 13.56 & 91.99 & 44294 \\
\hline $\mathrm{F}_{3}$ & 220.3 & 18.2 & 15.80 & 53.47 & 1.93 & 14.85 & 98.50 & 53200 \\
\hline S.Em \pm & 3.4 & 0.3 & 0.16 & 0.54 & 0.04 & 0.27 & 0.95 & 534 \\
\hline C. D. at $5 \%$ & 9.8 & 0.8 & 0.45 & 1.55 & 0.11 & 0.76 & 2.71 & 1526 \\
\hline C.V. $(\%)$ & 9.4 & 9.2 & 5.81 & 5.90 & 11.61 & 10.91 & 5.61 & 8 \\
\hline Interaction $(\mathrm{R} \times \mathrm{F})$ & NS & NS & NS & NS & NS & NS & Sig. & Sig. \\
\hline
\end{tabular}

$\mathrm{R}_{1}$ : No residue incorporation (Manual harvesting); $\mathrm{R}_{2}$ : Harvesting through combine harvester and burning the straw; $\mathrm{R}_{3}$ : Harvesting through combine harvester and straw incorporation in soil; $\mathrm{R}_{4}$ : Harvesting through combine harvester and straw incorporation in soil $+5 \mathrm{~kg} T$. viride $+25 \mathrm{~kg} \mathrm{~N}$ ha ${ }^{-1}$; $\mathrm{R}_{5}:$ harvesting through combine harvester and straw incorporation in soil $+5 \mathrm{~kg}$ madhyam $+25 \mathrm{~kg} \mathrm{~N} \mathrm{ha}^{-1}$

$\mathrm{F}_{1}$ : Control; $\mathrm{F}_{2}: 50 \% \mathrm{RDF} ; \mathrm{F}_{3}: 100 \% \mathrm{RDF}$ 
Table.2 Interaction effect of wheat residue management and fertilizer levels on dry matter plant ${ }^{-1}$

\begin{tabular}{cccccc}
\hline Fertilizer & \multicolumn{5}{c}{ Wheat residue management } \\
\cline { 2 - 5 } levels & $\mathrm{R}_{1}$ & $\mathrm{R}_{2}$ & $\mathrm{R}_{3}$ & $\mathrm{R}_{4}$ & $\mathrm{R}_{5}$ \\
\hline $\mathrm{F}_{1}$ & 77.22 & 79.15 & 84.63 & 94.97 & 97.59 \\
$\mathrm{~F}_{2}$ & 84.53 & 84.16 & 92.44 & 99.43 & 99.41 \\
$\mathrm{~F}_{3}$ & 96.72 & 85.44 & 98.39 & 101.82 & 110.16 \\
S.Em. \pm & & & 2.99 & & \\
C.D. at 5\% & & 8.56 & & \\
C.V. $(\%)$ & & & 5.61 & & \\
\hline
\end{tabular}

Table.3 Interaction effect of wheat residue management and fertilizer levels on Fodder yield of maize

\begin{tabular}{|c|c|c|c|c|c|}
\hline \multirow[t]{2}{*}{ Fertilizer levels } & \multicolumn{5}{|c|}{ Wheat residue management } \\
\hline & $\mathrm{R}_{1}$ & $\mathrm{R}_{2}$ & $\mathrm{R}_{3}$ & $\mathrm{R}_{4}$ & $\mathrm{R}_{5}$ \\
\hline $\mathrm{F}_{1}$ & 35449 & 33625 & 39533 & 41827 & 47908 \\
\hline $\mathrm{F}_{2}$ & 38771 & 36432 & 41415 & 52124 & 52728 \\
\hline $\mathrm{F}_{3}$ & 45588 & 42803 & 55927 & 60147 & 61536 \\
\hline S.Em. \pm & & & 1688 & & \\
\hline C.D. at $5 \%$ & & & 4826 & & \\
\hline C.V (\%) & & & 8 & & \\
\hline
\end{tabular}

\section{Effect of fertilizer levels}

Data presented in table: 1 indicated that fertilizing the crop with $100 \%$ RDF $\left(\mathrm{F}_{3}\right)$ registered significantly highest plant height $(220.3 \mathrm{~cm})$, number of leaves palnt ${ }^{-1}(18.2)$, leaf area index (15.80), leaf chlorophyll content $(53.47)$, stem diameter $(1.93 \mathrm{~cm})$, number of internodes palnt ${ }^{-1}(14.85)$ and dry matter plant ${ }^{-1}$ (98.50 g).

The improvement in growth parameters with application of $100 \%$ RDF might have resulted in better and timely availability of primary nutrients for their utilization by plant.

Profound influence of fertilizer on crop growth seems to be due to maintaining congenial nutritional environment on account of their greater availability from soil media. These findings are in consonance with those reported by Khot and Umrani (1992), Oad et al., (2004) and Arun Kumar et al., (2007). Result revealed in table 1 showed that significantly highest fodder $\left(53200 \mathrm{~kg} \mathrm{ha}^{-1}\right)$ was recorded under treatment $\mathrm{F}_{3}(100 \% \mathrm{RDF})$ over rest of the levels.
This may probably attributed to NPK being part of the essential nutrients required for the promotion of the meristematic and physiological activities such root development, plant dry matter production leading to an efficient absorption and translocation of water and nutrients, interception of solar radiation and assimilation of carbon dioxide. These activities promote higher photosynthetic activities leading to the production of enough assimilates for subsequent translocation towards sink and hence the production of higher yield.

These findings closely associated with those of Jalia et al., (2008) and Maqsood and Shehzad (2013).

\section{Interaction effect}

The data depicted in table 2 indicated that significantly higher dry matter plant-1 (110.16 g) was registered in treatment combination R5N3 (harvesting through combine harvester and straw incorporation in soil $+5 \mathrm{~kg}$ madhyam $+25 \mathrm{~kg} \mathrm{~N} \mathrm{ha}^{-1}$ along with $100 \% \mathrm{RDF}$ ) but it didn't significantly differed from R4N3 
(harvesting through combine harvester and straw incorporation in soil $+5 \mathrm{~kg} T$. viride +25 $\mathrm{kg} \mathrm{N} \mathrm{ha}^{-1}$ along with $100 \% \mathrm{RDF}$ ).

The result presented in table 3 revealed that treatment combination R5N3 (harvesting through combine harvester and straw incorporation in soil $+5 \mathrm{~kg}$ madhyam $+25 \mathrm{~kg} \mathrm{~N}$ $\mathrm{ha}^{-1}$ along with $100 \%$ RDF) registered higher fodder yield $\left(61536 \mathrm{~kg} \mathrm{ha}^{-1}\right)$ over rest of the treatment combinations but it was remained at par with R4N3 (harvesting through combine harvester and straw incorporation in soil $+5 \mathrm{~kg}$ T. viride $+25 \mathrm{~kg} \mathrm{~N} \mathrm{ha}^{-1}$ along with $\left.100 \% \mathrm{RDF}\right)$.

Based on the study, it can be concluded that effective management of what residues along with improved growth characters and higher fodder yield can be secured with adopting treatments likes harvesting through combine harvester and straw incorporation in soil $+5 \mathrm{~kg}$ madhyam $+25 \mathrm{~kg} \mathrm{~N}$ ha $^{-1}$ and harvesting through combine harvester and straw incorporation in soil $+5 \mathrm{~kg} \mathrm{~T}$. viride $+25 \mathrm{~kg} \mathrm{~N}$ $\mathrm{ha}^{-1}$ along with $100 \%$ RDF.

\section{References}

Arun Kumar, M. A., Gali, S. K. and Hebsur, S. N. 2007. Effect of different levels of NPK on growth and yield parameters of sweet corn. Karnataka Journal of Agricultural Science, 20(1): 41-43.

Cochran, W. G., and Cox, G. M. 1957. Experimental Designs. $2^{\text {nd }}$ ed. Wiley, New York.

Jaliya, M. M., Falaki, A. M., Mahmud, M. and Sani, Y. A. 2008. Effect of sowing date and NPK fertilizer rate on yield and yield components of quality protein maize (Zea mays L.). ARPN Journal of Agricultural and Biological Science, 3(2): 23-28.

Khot, R. B., and Umrani, N. K. 1992. Seed yield and qualityparameters of 'African tall' maize (Zea mays) as influenced by spacing and level of nitrogen. Indian Journal of Agronomy. 37(1): 183-184.

Maqsood, M., and Shehzad, A. M. 2013. Optimizing nitrogen input and harvest time to maximize the maize fodder yield in Punjab, Pakistan. Pakistan Journal of Agricultural Science, 50(1): 75-81.

Meena, B. L., and Singh, R. K. 2013. Response of wheat (Triticum aestivum) and rice (Oryza sativa) residue and weed management practices. Indian Journal of Agronomy, 58(4): 521-524.

Oad, F. C., Buriro, U. A. and Agha, S. K. 2004. Effect of organic and inorganic fertilizer application on maize fodder production. Asian Journal of Plant Science. 3(3): 375377.

Rajkhowa, D. J., and Borah, D. 2008. Effect of rice (oryza sativa) straw management on growth and yield of wheat (Triticum aestivum). Indian Journal of Agronomy, 53(2): 112-115.

Singh, R., and Yadav, D. S. 2006. Effect of rice (oryza sativa) residue and nitrogen on performance of wheat (Triticum aestivum) under rice- wheat cropping system. Indian Journal of Agronomy, 51(4): 247-250.

Singhal, V., 2003. Indian Agriculture. Indian Economic Data Research Centre, New Delhi.

Soleymani, A., shahrajabian, H. M. and Khoshkharam, M. 2016. The impact of barley residue management and tillage on forage maize. Romanian Agricultural Research, 33: 161-167.

\section{How to cite this article:}

Patil, A.S., B.M. Dabhi and Shitap, M.S. 2017. Effect of Wheat Residue Management and Fertilizer Levels on Growth and Yield of Fodder Maize (Zea mays L.). Int.J.Curr.Microbiol.App.Sci. 6(10): 25-29. doi: https://doi.org/10.20546/ijcmas.2017.610.004 